\title{
Development of an artificial vessel lined with human vascular cells
}

\author{
Helmut Gulbins, MDa \\ Martin Dauner ${ }^{b}$ \\ Robert Petzold ${ }^{\mathrm{a}}$ \\ Angelika Goldemund ${ }^{a}$ \\ Ingrid Anderson, $\mathrm{MS}^{\mathrm{a}}$ \\ Michael Doser ${ }^{b}$ \\ Bruno Meiser, MDa \\ Bruno Reichart, MD
}

\footnotetext{
From the Department of Cardiac Surgery, ${ }^{\mathrm{a}}$ University Hospital Grosshadern, LMU Munich, Germany, and the Institute of Textile and Process Engineering, ${ }^{\mathrm{b}}$ Denkendorf, Germany.

Received for publication Aug 5, 2003; revisions received Nov 19, 2003; accepted for publication Nov 20, 2003.

Address for reprints: Helmut Gulbins, MD, Department of Cardiac Surgery, University Hospital Grosshadern, LMU Munich, Germany, Marchioninistr. 15, D-81377 Munich, Germany (E-mail: Helmut.Gulbins@ med.uni-muenchen.de).

J Thorac Cardiovasc Surg 2004;128:372-7

$0022-5223 / \$ 30.00$

Copyright (C) 2003 by The American Association for Thoracic Surgery

doi:10.1016/j.jtcvs.2003.11.029
}

Objectives: Thrombogenity of small-diameter vascular prostheses might be reduced by complete coverage of the luminal surface with vascular cells. We investigated cell seeding on polyurethane vascular prostheses.

Methods: Thirty polyurethane vascular prostheses were divided into 3 groups of 10 each: group A, diameter of $20 \mathrm{~mm}$ and $\gamma$-sterilized; group B, diameter of $4 \mathrm{~mm}$ and $\gamma$-sterilized; and group $\mathrm{C}$, diameter of $4 \mathrm{~mm}$ and ethylene oxide sterilized. Human smooth muscle cells, fibroblasts, and endothelial cells were isolated from saphenous vein segments and expanded in culture. Five polyurethane vascular prostheses of each group were seeded with endothelial cells alone (mean, $4.8 \pm 1.2 \times 10^{6}$ cells), and the remaining 5 polyurethane vascular prostheses were preseeded with a mixed culture of fibroblasts and smooth muscle cells (mean, $7.7 \pm 2.3 \times 10^{6}$ cells), followed by endothelial cell seeding (mean, $4.4 \pm 0.9 \times 10^{6}$ cells). Seven days after cell seeding, the polyurethane vascular prostheses were perfused under a pulsatile flow ( $80 \mathrm{pulses} / \mathrm{min}, 140 / 80 \mathrm{~mm} \mathrm{Hg}$, and $120 \mathrm{~mL} / \mathrm{min}$ ) for 2 hours. Specimens were taken after each seeding procedure both before and after perfusion and then examined both with a scanning electron microscope and immunohistochemically.

Results: Isolated endothelial cell seeding revealed better initial adhesion in groups A and B than in group C (63\% vs 33\%). After 7 days, the cells had covered approximately $80 \%$ of the luminal surface in groups $\mathrm{A}$ and $\mathrm{B}$, whereas group $\mathrm{C}$ cells rounded up and lost adhesion. After perfusion testing of group A and B prostheses, only $10 \%$ of the surface was still covered with endothelial cells. Preseeding with the mixed culture again revealed a better initial adhesion in groups $\mathrm{A}$ and $\mathrm{B}$ compared with that in group C (76\% vs $41 \%)$. In groups A and B endothelial cell seeding (adhesion, 72\%) resulted in a confluent endothelial cell layer. The results of immunohistochemical staining were positive for collagen IV, laminin, CD31, and Factor VIII. In group C only isolated cells were found after each seeding procedure, which rounded up and vanished during the next days. Perfusion testing of group A and B prostheses revealed that the confluent cell layer remained stable, with only small defects ( $<10 \%$ of the surface). The cells stained positivively for endothelial nitric oxide synthase.

Conclusion: Seeding of a mixed culture out of fibroblasts and smooth muscle cells resulted in improved endothelial cell adhesion and resistance to shear stress. This outcome was caused by an increased synthesis of extracellular matrix proteins. Cell attachment was better on $\gamma$-sterilized polyurethane vascular prostheses compared with on those undergoing ethylene oxide sterilization. 

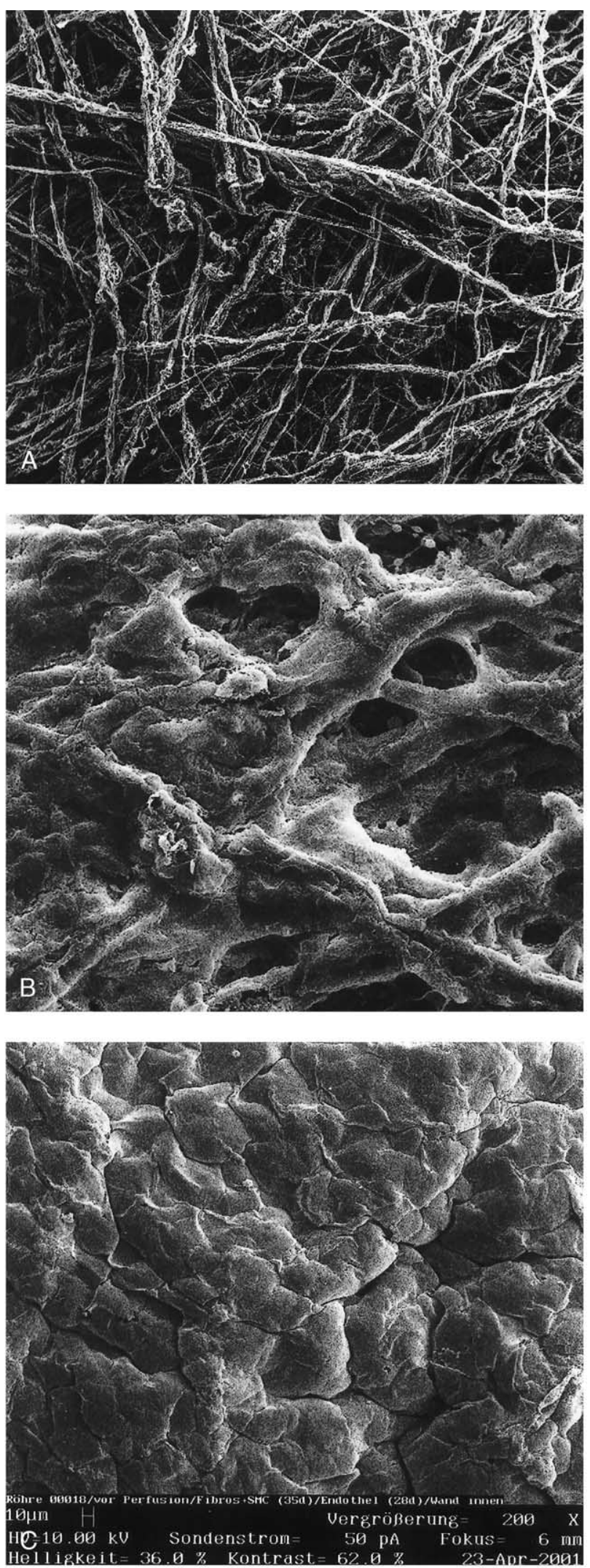

Figure 1. A, SEM, native polyurethane prostheses. The polyurethane fibers form a surface imitating that of de-endothalilized biologic prostheses (eg, homgrafts). (Original magnification $200 \times$.) B, SEM, native polyurethane prostheses after seeding of fibroblasts and SMCs. The polyurethane fibers are covered by fibroblasts and SMCs, which cannot be differentiated from each other with SEM. However, no free-lying polyurethane fibers can be identified. (Original magnification: $200 \times$.) C, SEM, native polyurethane prostheses after preseeding with fibroblasts and SMCs and final seeding with ECs. The complete surface is covered with ECs exhibiting the typical cobblestone morphology of ECs under culture conditions. (Original magnification: $200 \times$.)

pellet was resuspended in fibroblast growth medium (low serum, ready to use; Promocell) and plated on culture dishes.

After EC and fibroblast culturing, the vein pieces were opened longitudinaly, and the adventitia was removed. The remaining tissue was cut into small pieces of approximately 2 to $4 \mathrm{~mm}^{2}$ and placed beneath a cover glass fixed by means of 4 silicone drops onto the culture dish. Smooth muscle cell medium (smooth muscle cell basal medium; Cell Systems, Katherinen, Germany) with $10 \%$ fetal calf serum and supplements (smooth muscle cell basal medium kit; Cell systems) was added. For evaluation of the cultured cells and identification as SMCs, cultured cells were stained with an $\alpha$-actin antibody. The vein pieces were left over from routine aortocoronary bypass operations, and the patients had given their informed consent that the pieces could be used in the laboratory. The local ethics committee approved the anonymous use of the saphenous vein pieces for this experimental study.

The complete experimental design is shown in the flow chart (Table 2). Seven days after EC seeding, the grafts were exposed to shear stress. The PUVPs were anastomosed to unseeded vascular grafts (Vascutek, Baxter Healthcare, Puerto Rico) and placed in a perfusion chamber. Flow started at 30 to $40 \mathrm{~mL} / \mathrm{min}$ at 80 pulses per minute, resulting in a pressure of $50 / 30 \mathrm{~mm} \mathrm{Hg}$. This was done to allow the cells to adapt to shear stress. Flow was increased to $120 \mathrm{~mL} / \mathrm{min}$ after 30 minutes, resulting in a pressure of $140 / 80 \mathrm{~mm}$ $\mathrm{Hg}$. Total shear stress testing lasted for 2 hours.

For immunohistochemical staining, sections of 8-mm thickness were stained by using monoclonal antibodies for Factor VIII, laminin, $\alpha$-actin, CD31 (Dako, Hamburg, Germany), and collagen IV (Sigma, Deisnhofen, Germany). For Factor VIII staining, a polyclonal antibody for anti-rabbit IgG (Immundiagnostik, Bensheim, Germany) was used. Collagen IV, laminin, $\alpha$-actin, endothelial nitric oxide synthase (eNOS), and CD31 stainings were counterstained with an anti-mouse IgG antibody (Dako) and stained with AEC (Dako). The results were validated by using negative control stainings without the primary antibody.

The techniques for scanning electron microscopy (SEM) are described elsewhere. ${ }^{17}$ Only cell layers with the typical cobblestone morphology were accepted as EC layers. For analysis, 10 visual fields of each specimen were evaluated at $200 \times$ magnification. EC covering was assessed semiquantitatively by 2 examiners and classified as $100 \%, 75 \%, 50 \%$, or $25 \%$. A mean value of $95 \%$ or greater was thought to represent a confluent EC layer. Unseeded PUVP specimens served as negative controls. All values are given as means \pm SD. For statistical analysis, the paired Student $t$ test was used. 
TABLE 3. Results of the seeding procedures onto the different groups of prostheses

\begin{tabular}{|c|c|c|c|c|c|c|}
\hline & \multicolumn{2}{|c|}{ Group A PUVPs (20 mm, $\gamma$-sterilized) } & \multicolumn{2}{|c|}{ Group B PUVPs (4 mm, $\gamma$-sterilized) } & \multicolumn{2}{|c|}{ Group C PUVPs (4 mm, Eto sterilized) } \\
\hline & $\begin{array}{l}\text { Isolated EC } \\
\text { seeding }\end{array}$ & $\begin{array}{l}\text { Preseeding with } \\
\text { FBs and SMCs }\end{array}$ & $\begin{array}{l}\text { Isolated EC } \\
\text { seeding }\end{array}$ & $\begin{array}{l}\text { Preseeding with } \\
\text { FBs and SMCs }\end{array}$ & $\begin{array}{l}\text { Isolated EC } \\
\text { seeding }\end{array}$ & $\begin{array}{c}\text { Preseeding with FBs } \\
\text { and SMCs }\end{array}$ \\
\hline $\begin{array}{l}\text { FB and SMC } \\
\text { seeding }\end{array}$ & - & $\begin{array}{l}\text { Initial adhesion: } \\
76 \% \pm 8 \% \text {. } \\
\text { Confluent cell } \\
\text { layer, viable } \\
\text { cells }\end{array}$ & - & $\begin{array}{l}\text { Initial adhesion: } \\
76 \% \pm 8 \% \text {. } \\
\text { Confluent cell } \\
\text { layer, viable } \\
\text { cells }\end{array}$ & - & $\begin{array}{l}\text { Initial adhesion: } 41 \\
\pm 7 \% \text {. Isolated } \\
\text { attached cells, } \\
\text { cell loss after } 7 \mathrm{~d}\end{array}$ \\
\hline EC seeding & $\begin{array}{l}\text { Initial } \\
\text { adhesion: } \\
63 \% \pm 6 \% \text {. } \\
\text { Cell layer } \\
\text { covering } \\
80 \% \text { of the } \\
\text { surface, } \\
\text { viable cells }\end{array}$ & $\begin{array}{l}\text { Initial adhesion: } \\
72 \% \pm 7 \% \text {. } \\
\text { Confluent cell } \\
\text { layer, viable } \\
\text { cells }\end{array}$ & $\begin{array}{l}\text { Initial } \\
\text { adhesion: } \\
63 \% \pm 6 \% \text {. } \\
\text { Cell layer } \\
\text { covering } \\
80 \% \text { of the } \\
\text { surface, } \\
\text { viable cells }\end{array}$ & $\begin{array}{l}\text { Initial adhesion: } \\
72 \% \pm 7 \% \text {. } \\
\text { Confluent cell } \\
\text { layer, viable } \\
\text { cells }\end{array}$ & $\begin{array}{l}\text { Initial } \\
\text { adhesion: } \\
33 \% \pm 7 \% \text {. } \\
\text { Rare EC, } \\
\text { complete } \\
\text { cell loss } \\
\text { after } 7 \mathrm{~d}\end{array}$ & $\begin{array}{l}\text { Initial adhesion: } \\
31 \% \pm 5 \% \text {. } \\
\text { Isolated attached } \\
\text { cells, cell loss } \\
\text { after } 7 \mathrm{~d}\end{array}$ \\
\hline Perfusion for $2 \mathrm{~h}$ & $\begin{array}{l}\text { Defects } \\
\text { within the } \\
\text { cell layer, } \\
\text { viable cells } \\
(>90 \%)\end{array}$ & $\begin{array}{l}\text { Confluent cell } \\
\text { layer, viable } \\
\text { cells }\end{array}$ & $\begin{array}{l}\text { Defects } \\
\text { within the } \\
\text { cell layer, } \\
\text { viable cells } \\
(>90 \%)\end{array}$ & $\begin{array}{l}\text { Confluent cell } \\
\text { layer, viable } \\
\text { cells }\end{array}$ & - & - \\
\hline
\end{tabular}

Whereas preseeding with fibroblasts and smooth-muscle cells resulted in confluent cell layers on group $A$ and $B$ prostheses even after perfusion, isolated endothelial cell seeding resulted in a particular cell loss during perfusion. On group $C$ prostheses, initial adhesion and cell attachment were poor, and most of the cells were lost before perfusion.

PUVP, Polyurethane vascular prostheses; $E C$, endothelial cell; $F B$, fibroblast; $S M C$, smooth muscle cell.

\section{Results}

After cell seeding, the anastomoses to the vascular prostheses in the perfusion system proved to be unproblematic. No splitting of the tissue at the anastomtic sides was seen in any of the prostheses. The surface of the native PUVPs looked similar to the probes of native homografts on SEM (Figure $1, A)$. The results of the seeding procedures and perfusion are summarized in Table 3. Because of the poor results of cell seeding on group C PUVPs, these prostheses were not exposed to shear stress.

\section{Isolated EC Seeding}

For groups $\mathrm{A}$ and $\mathrm{B}$, there was coverage of $80 \% \pm 11 \%$ of the surface with viable ECs (Figure 2). Staining results for collagen IV, eNOS, and laminin were negative. After flow testing, only isolated cells remained on the surface; the covering reached a maximum of $10 \%$ of the luminal surface. Few cells were proved to be viable on the basis of staining for Factor VIII and CD31. The results of staining for eNOS remained negative.

\section{Preseeding With Autologous Fibroblasts and SMCs}

For groups A and B, fibroblasts and SMCs formed a confluent cell layer (Figure 1, B). SMC viability was demonstrated on the basis of positive staining for $\alpha$-actin. For group C, SEM images only showed isolated cell islands distributed over the entire surface. Few cells could be con- firmed as SMCs on the basis of positive stainig for $\alpha$-actin. For group A and B prostheses, the cells stained strongly positive for CD31 and Factor VIII. Stainings for collagen IV and laminin were also strongly positive on group A and B PUVPs, whereas the results of eNOS staining were negative. For group $\mathrm{C}$ prostheses, only few cells stained positive for CD31 and Factor VIII (Figure 3). The results of staining for collagen IV, laminin, and eNOS remained negative. The EC layer on group A and B PUVPs remained stable after the flow testing (Figure 4). The cells had changed their shape slightly, beginning to orientate themselves according to the flow direction. The cells still stained positive for Factor VIII and CD31 (Figure 5). Additionally, the cells now stained positive for eNOS as a reaction to the shear stress.

\section{Discussion}

Experimentally, the link between ECs and the scaffold was shown to be of great importance in tissue engineering. ${ }^{3-10,12-14}$ ECs adhered better and proved to be more resistant to shear stress on prostheses precoated with different extracellular matrix proteins. ${ }^{7,8}$ Precoating with fibrin glue was reported to be successful under in vitro conditions. ${ }^{13,14} \mathrm{ECs}$, however, start fibrinolysis under physiologic conditions when they come in contact with fibrin. Therefore they would probably disintegrate this artifical and unphysiologic matrix, thus reducing adhesion with subsequent cell 


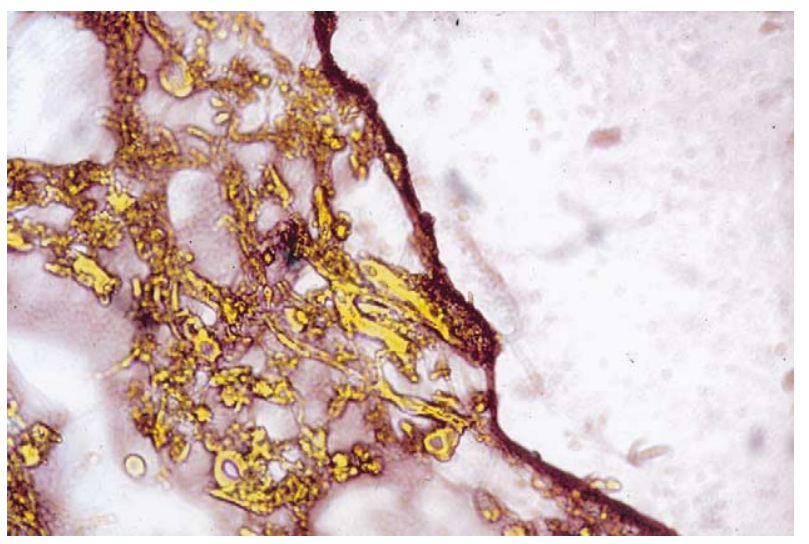

Figure 2. Group B PUVP, immunohistochemical staining for CD31, peroxidase reaction. A small band of a positive reaction (dark red band) on the luminal surface indicates viable ECs. (Original magnification $100 \times$.)

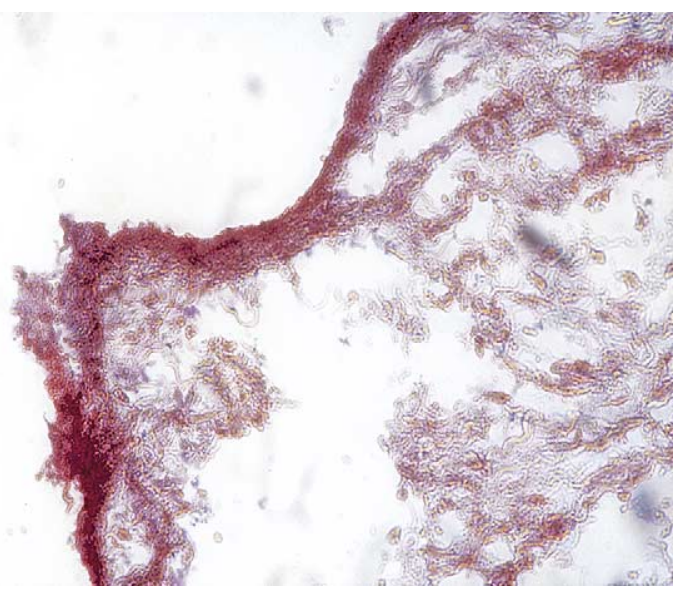

Figure 3. Group C PUVPs, immunohistochemical staining for CD31, peroxidase reaction. Only rare ECs stain positive for CD31 (red, only rare clear positive signals), whereas most parts of the surface remain negative. The poor cell attachment on group $\mathrm{C}$ PUVPs is indicated. (Original magnification $100 \times$.)

loss. In contrast to artificial precoating of the prosthetic surface, the synthesis of the extracellular matrix proteins by interstitial or other vascular cells could improve the link between ECs and the surface. Excellent adhesion of ECs was shown on the extracellular matrix built with fibroblasts. ${ }^{8,18}$ Fibroblasts and SMCs represent the physiologic substrate on which ECs attach. Together with these cells, ECs synthetized their own extracellular matrix and formed a basement membrane that was proved by the increased synthesis of collagen IV and laminin on prostheses preseeded with fibroblasts and SMCs compared with isolated EC seeding. ECs seeded on these grafts showed a higher resistance to shear stress, and a confluent layer was main-

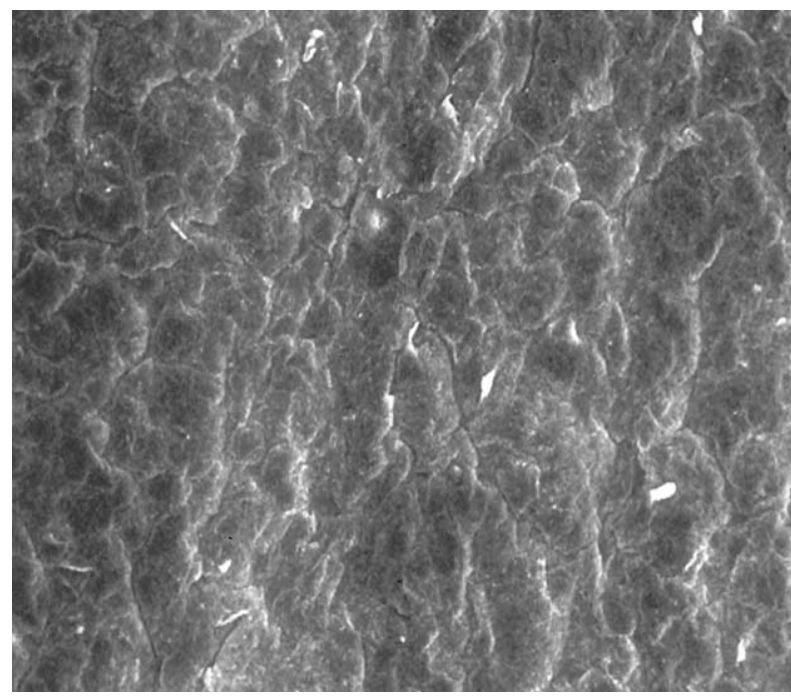

Figure 4. Group B PUVPs, SEM, after 4 hours' perfusion. A confluent EC layer is seen. The cells have flattened a little bit as a reaction to the exposure to shear stress. (Original magnification $200 \times$.)

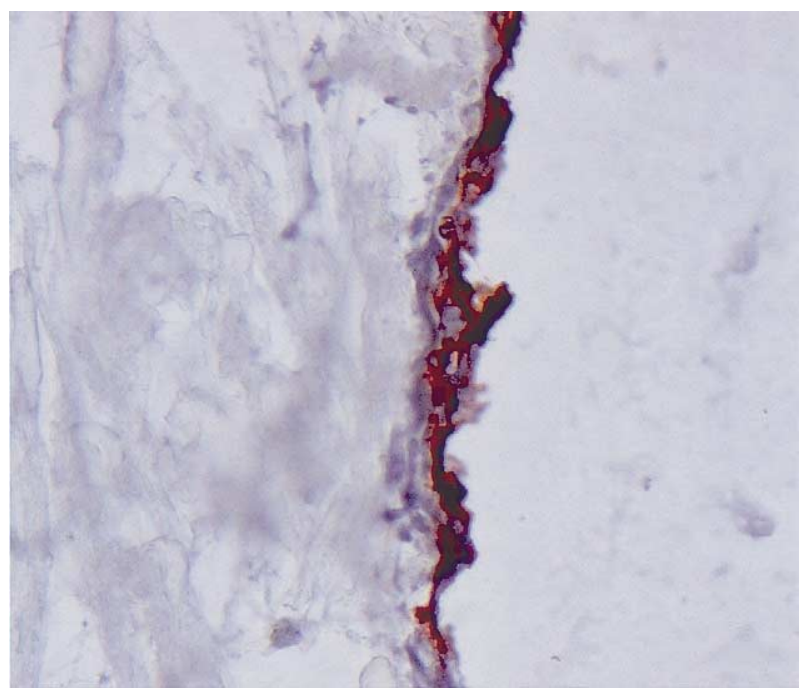

Figure 5. Group B PUVPs after 4 hours' perfusion, immunohistochemical staining for collagen IV, peroxidase reaction. The cells on the luminal surface still stain positive for collagen IV (dark red signal on the luminal surface), identifying this important component of the basement membrane. (Original magnification $200 \times$.)

tained. This finding supported the hypothesis that fibroblasts and SMCs were of great importance for the synthesis of the extracellular matrix and that intercellular interactions contribute to improved adhesion.

EC seeding on polyurethane surfaces has been described previously. ${ }^{6}$ The vascular prostheses presented in our experiments were a melt-blown polyurethane, a manufactur- 
ing process resulting in a surface built of innumerable thin fibers. These fibers formed a network imitating that of collagen fibers. This structured surface was well suited to cell attachment, especially for fibroblasts and SMCs. Onto the confluent cell layer of these cells, ECs showed excellent attachment and adhesion. The sterilization process was of great importance for cell seeding, attachment, and survival. In our experiments ethylene oxide sterilization resulted in poor cell attachment and survival, whereas $\gamma$-sterilization had no adverse effect. Chemical alterations of the surface caused by the reactive ethylene oxide might have been one reason for this. Another possible explanation was an incomplete wash out of the ethylene oxide during the 4-hour washing period, resulting in a further ethylene oxide release.

The flow-testing protocol did not simulate physiologic conditions completely because viscosity is an important factor influencing shear stress. Blood does not behave like an ideal fluid, thus causing additional forces on the EC layer compared with those caused by a cell-free medium. The grafts will have to prove their resistance to physiologic shear stress in animal experiments. The protocol, however, was useful to show that isolated EC seeding was not successful in establishing a shear stress-resistant confluent EC layer. The EC layer was lost under perfusion, although the applied shear stress under in vitro conditions was smaller than that under in vivo settings.

In conclusion, seeding of human ECs on melt-blown polyurethane was possible. Preseeding with autologous fibroblasts and SMCs improved EC adhesion and shear-stress resistance. Animal experiments are necessary to prove patency rates under physiologic conditions.

\section{References}

1. Barner HB. Arterial grafting: techniques and conduits. Ann Thorac Surg. 1998;66(suppl):S2-5.

2. Canver CC. Conduit options in coronary artery bypass surgery. Chest. 1995;108:1150-5.

3. Bengtsson L, Radegran K, Haegerstrand A. A new and simple technique to achieve a confluent and flow resistant endothelium on vascular ePTFE-grafts using human serum. Eur J Vasc Surg. 1994;8: $182-7$.
4. Consigny PM, Vitali NJ. Resistance of freshly adherent endothelial cells to detachment by shear stress is matrix and time dependent. $J$ Vasc Interv Radiol. 1998;9:479-85.

5. Fernandez P, Bareille R, Conrad V, Midy D, Bordenave L. Evaluation of an in vitro endothelialized vascular graft under pulsatile shear stress with a novel radiolabeling procedure. Biomaterials. 2001;22:649-58.

6. Giudiceandrea A, Seifalian AM, Krijgsman B, Hamilton G. Effect of prolonged pulsatile shear stress in vitro on endothelial cell seeded PTFE and compliant polyurethane vascular grafts. Eur J Endovasc Surg. 1998;15:147-54.

7. Kadletz M, Moser R, Preiss P, Deutsch M, Zilla O, Fasol R. In vitro lining of fibronectin coated PTFE grafts with cryopreserved saphenous vein endothelial cells. Thorac Cardiovasc Surg. 1987;35:143-7.

8. Lee Y-S, Park DK, Kim YB, Seo JW, Lee KB, Min BG. Endothelial cell seeding onto the extracellular matrix of fibroblasts for the development of a small diameter polyurethane vessel. ASAIO J. 1993;39: M740-5.

9. Miyata T, Conte MS, Trudelli LA, Mason D, Whittemore AD, Birinyi LK. Delayed exposure to pulsatile shear stress improves retention of human saphenous vein endothelial cells on seeded ePTFE grafts. J Surg Res. 1991;50:485-93.

10. Rademacher A, Paulitschke M, Meyer R, Hetzer R. Endothelialization of PTFE vascular grafts under flow induces significant cell changes. Int J Artif Organs. 2001;24:235-42.

11. Sentissi JM, Ramberg K, O'Donnell TF, Conolly RJ, Callow AD. The effect of flow on vascular endothelial cells grown in tissue culture on polytetrafluoroethylene grafts. Surgery. 1986;99:337-43.

12. Shi Q, Wu MH-D, Onuki Y, Kouchi Y, Ghali R, Wechezak AR, et al. The effect of flow shear stress on endothelialization of impervious dacron grafts from circulating cells in the arterial and venous systems of the same dog. Ann Vasc Surg. 1998;12:341-8.

13. Muller-Glauser W, Zilla P, Lachat M, Bisang B, Rieser F, von Segesser $\mathrm{L}$, et al. Immediate shear stress resistance of endothelial cell monolayers seeded in vitro on fibrin glue-coated ePTFE prostheses. Eur J Vasc Surg. 1993;7:324-8.

14. Zilla P, Fasol R, Preiss P, Kadletz M, Deutsch M, Schima H, et al. Use of fibrin glue as a substrate for in vitro endothelialization of PTFE vascular grafts. Surgery. 1989;105:515-22.

15. Gulbins H, Goldemund A, Anderson I, Haas U, Uhlig A, Meiser B, et al. Preseeding with autologous fibroblasts improves endothelialization of glutaraldehyde-fixed porcine aortic valves. J Thorac Cardiovasc Surg. 2003;125(3):592-601.

16. Nishida M, Carley WW, Gerritsen ME, Ellingsen O, Kelly RA, Smith TW. Isolation and characterization of human and rat cardiac microvascular endothelial cells. Am J Physiol. 1993;264:H639-52.

17. Plattner H, Zingsheim HP. Electron microscopical techniques in cell and molecular biology. Stuttgart: Gustav Fischer Verlag; 1987. p. 335-95.

18. Fridman R, Alon Y, Doljanski F, Fuks Z, Vlodavski I. Cell interaction with the extracellular matrices produced by endothelial cells and fibroblasts. Exp Cell Res. 1985;158:461-76. 